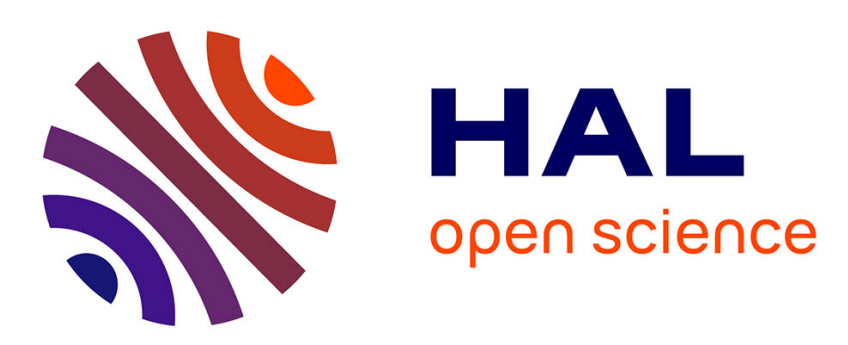

\title{
Measuring the voice of disciplinarity in scientific writing: A longitudinal exploration of experienced writers in geology
}

Dacia Dressen-Hammouda

\section{- To cite this version:}

Dacia Dressen-Hammouda. Measuring the voice of disciplinarity in scientific writing: A longitudinal exploration of experienced writers in geology. English for Specific Purposes, 2014, 34, pp.14-25. 10.1016/j.esp.2013.10.001 . hal-01015090

\author{
HAL Id: hal-01015090 \\ https://hal.uca.fr/hal-01015090
}

Submitted on 25 Jun 2014

HAL is a multi-disciplinary open access archive for the deposit and dissemination of scientific research documents, whether they are published or not. The documents may come from teaching and research institutions in France or abroad, or from public or private research centers.
L'archive ouverte pluridisciplinaire HAL, est destinée au dépôt et à la diffusion de documents scientifiques de niveau recherche, publiés ou non, émanant des établissements d'enseignement et de recherche français ou étrangers, des laboratoires publics ou privés. 


\title{
Measuring the voice of disciplinarity in scientific writing: A longitudinal exploration of experienced writers in geology
}

\author{
Dacia Dressen-Hammouda
}

\author{
Université Blaise Pascal, Clermont 2, Laboratoire ACTé (Action, Connaissances, Transmission, Éducation), \\ 34, avenue Carnot, 63037 Clermont-Ferrand Cedex, France
}

\begin{abstract}
A significant number of studies have examined the features of expert discoursal practices in science and academia, and many have focused on what happens to student writers working their way into the academic community. Less attention has been paid to how a scientific writer's voice continues to change after the Ph.D. dissertation. This study examines the shift in experienced scientific writers' disciplinary voice over the ten-year period following the doctoral dissertation. Using genre analysis triangulated with qualitative methods, a set of indexes that convey field geologists' disciplinary practices and concerns has been identified. Using a measure of standard deviation, the study then compares the use of these indexes by six writers from geology over ten years, and finds that disciplinary voice develops in similar ways. This paper contributes to ongoing discussions about how research on voice is useful for studies on second-language writing. In addition, using tools such as standard deviation allows for a closer analysis of the elusive notion of 'voice'.
\end{abstract}

Keywords:

Disciplinary voice ; Geology ; Indexicality ; Longitudinal study ; Situated genre analysis ; Standard deviation (SD) analysis`

\section{Introduction}

A general consensus today supports the idea that voice is relevant to academic and scientific writing, as seen for example in the high-stakes context of international scientific publishing (Belcher, 2007; Lillis \& Curry, 2010). Taking the blind manuscript review as an example (Tardy \& Matsuda, 2009), the disadvantages faced by L2 writers are seen to stem from the way in which they use-or fail to use - the expected features of voice. Voice is also viewed as very relevant to L2 writing pedagogy. Hyland (2005a, p. 365), for example, has observed that "writers must both present themselves as competent individuals, expressing a textual 'voice' or community recognised personality, and engage with readers in accepted ways.' However, the need to display an 'appropriate voice' often poses challenges for L2 writers, who not only need to learn the voice of their disciplines, but often also of an L2 culture. As noted by Ramanathan and Kaplan (1996, p. 22), for example, "audience and voice are largely culturally constrained notions, relatively inaccessible to students who are not full participants in the culture within which they are asked to write.' Nonetheless, L2 student writers are consistently judged according to the same standards as their L1 peers, as observed in statewide examinations and standardized testing (Zhao \& Llosa, 2008) and in the large-scale criteria developed for evaluating essays (Matsuda \& Jeffery, 2012). Similarly, Davies, Hamp-Lyons, and Kemp (2003), Jarvis, Grant, Bikowski, and Ferris (2003), Hyland and Anan (2006) and Leki (2006) provide further evidence about how the presence or absence of the features of (L1) voice in L2 writing influence evaluator/teacher attitudes.

Although voice is clearly a central issue in L2 writing research and pedagogy, there have been relatively few attempts to move the discussion of voice beyond a somewhat reductive view as 'unique authorial presence and opinion', although recent research suggests that voice is actually far more complex (Hirvela \& Belcher, 2001; Hyland \& Sancho Guinda, 2012; Ivanic ${ }^{`} \&$ Camps, 2001; Matsuda, 2001; Matsuda \& Tardy, 2007; Prior, 2001; Tardy, 2012; Tardy \& Matsuda, 2009). This paper will first discuss why a broader definition of voice is not more common in the research literature. It will then demonstrate a method for analyzing voice by presenting results from a longitudinal study of the individual writing strategies of six increasingly experienced scientific writers during the ten-year period following their 
Ph.D. dissertation. Using standard deviation (SD) analysis, the study looks specifically at how the writers' disciplinary voice changes over time. The results provide evidence as to why further research on individuals' disciplinary voice, using an expanded definition, is both important and useful for L2 writing research and pedagogy.

\section{Voice and L2 writing research}

Despite undeniable interest among L2 writing specialists, voice remains a contentious topic. Even today, there is far from absolute agreement about the extent to which voice may actually be relevant to L2 teaching needs. An earlier, but emblematic, illustration of this disagreement can be observed in a special issue dedicated to voice in L2 writing research and pedagogy (Journal of Second Language Writing, 2001, Volume 10, Issues 1-2) as well as in a later series of articles that build on this earlier exchange (HelmsPark \& Stapleton, 2003; Matsuda \& Tardy, 2007, 2008; Stapleton, 2002; Stapleton \& HelmsPark, 2008; Tardy \& Matsuda, 2009).

One criticism often leveled against teaching voice is that it may be less relevant for new or less experienced L2 writers. In response to Matsuda and Tardy (2007), for example, who defend the position that voice is inherent to all academic writing, Stapleton and Helms-Park (2008) concede that while voice is not unimportant, there is concern that new or less experienced L2 writers have other, more pressing issues to attend to, such as grammar, syntax, or vocabulary. In addition, they found that teaching the 'features of voice' (e.g., first person, deontic modals) had little effect on the development of students' writing strategies (Stapleton \& Helms-Park, 2008).

The reservations articulated by Stapleton and Helms-Park appear to stem in part from their approach to voice, which they described using a priori categories based on the Voice Intensity Rating Scale (HelmsPark \& Stapleton, 2003; Stapleton, 2002), including first person pronouns, deontic modals, and selfgenerated assertions (Stapleton \& Helms-Park, 2008, p. 95). It must be noted, however, that such categories isolate the teaching of grammar from its immediate social context. As a consequence, the authors lack a theoretical and empirical basis for describing the situated grammatical and lexical choices reflected in voice. In contrast, Matsuda and Tardy $(2007,2008)$ advocate an approach to voice grounded in immediate social context. Although their 2007 study was sharply criticized for devising a set of socalled "a posteriori categories" (Stapleton \& Helms-Park, 2008, p. 96), and admittedly did not establish a correlation between reader reaction and any specific features of disciplinary voice, their subsequent study (Tardy \& Matsuda, 2009) considerably extends the strength of their claims. Through surveys with 70 manuscript reviewers, they show that reviewers do indeed rely on a set of ideational and rhetorical categories to build their perception of an author's disciplinary identity and level of experience. Such relevant features, they argue, can only be identified a posteriori, i.e., with regard to the specific sociocultural context that creates voice.

A second criticism often leveled against teaching and researching voice is that the way in which a single individual writes should not be taken as a basis for describing writing behavior in general. Swales (1990, 2004), for one, has long argued that it is not what is unique to individual writing but what is common to a group of individuals' writing that holds value for L2 writing pedagogy. The underlying position is that a writing research and teaching agenda that focuses primarily on individual variation would be ill-adapted to the specific needs of L 2 writers, who need instruction in the commonalities of the new discourses they must learn, rather than in the idiosyncrasies of their users.

Such reservations about the usefulness of voice for L2 writing pedagogy, however, appear to be rooted in how voice is defined. In effect, voice is often equated with 'individuality', 'uniqueness' or 'personal stamp' (Elbow, 1994), and is viewed as an ideal to be attained in scholarly writing. Many writing teachers and researchers assume that L2 student writers must be taught voice (being clear, overt, assertive) and usefully point to specific linguistic markers such as self-mention, boosters, and hedges. However, a number of studies have cautioned against conflating voice with a cultural ideology of 'Western-style' 
individualism (Hirvela \& Belcher, 2001; Ramanathan \& Atkinson, 1999). It has been argued that such notions of individualism - which are undeniably Anglo-American - represent but one possible cultural frame among many, all of which construct differing, sometimes diametrically opposed, impressions of voice.

In this paper, I argue for the need to once again move the discussion of voice beyond culturally based notions of 'unique authorial presence and opinion', toward a more expanded social view. Sharing Tardy's (2012) inclusive position that voice encompasses three dimensions - individual, social, and dialogical, I adopt a view of voice as one which naturally reflects the multiple voices ('heteroglossia', Bakhtin, 1981) to which an individual has been exposed in specific situations. Voice is an individual's natural "selfrepresentation'" in writing (Ivanic ${ }^{2} \&$ Camps, 2001, p. 4), the need for which is unavoidable and constant. Using culturally available semiotic resources, people continuously project their self-representation to others through their physical appearance and body language, as well as through their spoken language, word choice and prosody. Writing is no exception to this behavior, and writers clearly portray aspects of their individual and social identity to readers through their voice. People construct the voice they use to portray themselves with using the borrowed and culturally available resources of the community(ies) they have learned to address. Voice is thus an individual's response to social interaction. It is also a sociocultural construct, tied closely to an individual's experience with a community's practices, its semiotic resources and validated ways of speaking. In this regard, voice also reflects the extent of one's legitimized participation in that community (Lave \& Wenger, 1991). Voice is also dialogical: It is the reader's impression of the writer's attempts to position her or himself by using a particular combination of discursive and non-discursive features (Matsuda \& Tardy, 2007, p. 239). Voice, therefore, is not reducible to an isolated set of linguistic features, but is "the amalgamative effect of a [whole] range of features" (Tardy \& Matsuda, 2009, p. 43) that construct and maintain the relationship between writer and reader. In other words, voice helps to create a co-constructed, shared sociocognitive space that allows readers and writers to situate one another. Such an expanded view of voice has been gaining increasing recognition in the research literature (Hirvela \& Belcher, 2001; Hyland \& Sancho Guinda, 2012; Ivanic ${ }^{2} \&$ Camps, 2001; Matsuda, 2001; Matsuda \& Tardy, 2007; Prior, 2001; Tardy, 2012; Tardy \& Matsuda, 2009); viewing voice merely as 'individuality' or 'personal stamp' is too reductive because it fails to capture the multiple facets of voice, which is situated on many levels, including socio-economic/family background, profession, and national culture. While certain traits that call up 'individuality' or 'personal stamp' are more associated with specifically cultural notions of voice, and constitute a valuable topic of research for some L2 writing contexts, the emphasis in the present paper will be placed instead on aspects of disciplinary voice.

That being said, voice remains a complex object to identify, analyze and quantify. Indeed, while by all accounts an author's voice has a distinct quality that is discernible by readers, strongly influencing how they evaluate the writer's success, a number of scholars have underscored how difficult it is to actually identify voice in terms of isolated linguistic or rhetorical features (Atkinson, 2001; Elbow, 1999; HelmsPark \& Stapleton, 2003; Tardy, 2012; Tardy \& Matsuda, 2009). Voice seems to have "ineffable qualities" (Atkinson, 2001, p. 110), to foreground "a dimension of the text that is rhetorically powerful but hard to focus on: the implied and unspoken meanings that are carried in the text but that are different from the clear and overt meanings of the words"' (Elbow, 1999, p. 336).

A variety of frameworks reveal various aspects of voice, such as interpersonality (Mur-Dueñas, LorésSanz, \& LafuenteMillán, 2010), engagement (Hyland, 2005b), proximity (Hyland, 2010), evaluation (Hunston \& Thompson, 2000), or hedging (Hyland, 1998; Salager-Meyer, 1994). However, as suggested by Hyland and Sancho Guinda (2012), such frameworks are subsumed within the larger phenomenon of voice, and none effectively captures all of the broad impressions about social identity voice conveys. One framework of particular interest for describing these 'broad impressions' is indexicality (Blommaert, 2010; Bucholtz \& Hall, 2005; Dressen-Hammouda, 2013; Lillis, 2008; Ochs, 1992). An 'index' is the implicit, semiotic relationship that arises between two forms. As a result of repeated juxtaposition between the two forms, one form conjures up another although it may no longer be explicit (e.g., smoke evokes 
fire). Because the one-to-one correspondence between the two forms gradually 'disappears', a specific linguistic form becomes associated with, or presupposes, a particular social meaning, and using that form creates the perception of meaning although that meaning is not expressed explicitly. An index is thus a "linguistic form that depends on the interactional context for its meaning. . . involv[ing] the creation of semiotic links between linguistic forms and social meanings', (Bucholtz \& Hall, 2005, p. 594). The implied meaning of an index is understood because informed insiders have learned to make semiotic associations over time. It is suggested here that the 'ineffable nature' of voice can perhaps best be described through indexicality, thus answering to L2 voice research's need for identifiability, categorizability, and quantifiability.

The framework of indexicality opens up avenues for examining disciplinary voice if one accepts that what creates the perception of disciplinary voice is the indexical relationship between the implicit knowledge and interpretations people share in a disciplinary community and the visible, linguistic features of the genres they use to interact. An individual's disciplinary voice 'carries' the indexical meanings of disciplinary experience and identity, and is social, individual, and dialogical (Tardy, 2012). The idea that voice carries traces of indexicality finds an echo in the existing literature on L2 writing research. For example, Matsuda and Tardy (2007, p. 239) discuss how voice is the "reader's impression" of the writer's attempts to position her or himself by combining discursive and non-discursive features in particular ways. Tardy $(2012$, p. 46) further explains how, while one of the reviewers from their survey was unable to identify the specific features in the text that led to his impressions, he did rely on "more of a general sense he built'. In contrast to Tardy and Matsuda (2009), who have investigated the combined overall effect of voice, the current paper will focus instead on how to identify and measure specific features of disciplinary voice which may provide readers with such a 'general sense'.

In the following sections, I will discuss how the features of disciplinary voice may be identified, categorized, quantified, and analyzed over time. In this paper, disciplinary voice is understood to carry the indexes of disciplinary experience, and consequently, to portray an individual's disciplinary identity. In addition, because identifying relevant indexes requires creating a posteriori categories based on the empirical analysis of context, rather than a priori categories based on pre-existing, socially decontextualized categories, I will also argue that it is necessary to combine genre analysis with other qualitative methods. The socially relevant - and therefore pedagogically useful-features of disciplinary voice can only emerge after a careful examination of the actual practices and/or sociohistorical context of a disciplinary community.

\section{Methods}

The present study describes how disciplinary voice shifts over a period of ten years, as researchers move from junior scholar to more experienced scholar status. This particular time span was chosen since the construction of expertise appears to follow a 'ten-year rule' (Ericsson, 2006). The central question to be answered is how to identify and measure the linguistic features that index this shift. The analysis focuses specifically on one type of scientific writing, the field account (Dressen-Hammouda, 2008), which occurs as a specific subsection in geology articles that report specifically on field research; therefore, not all research articles in geology contain a field account.

To track the development of disciplinary voice over time, two primary methods were used: a situated genre analysis (Ahmad, 1997) and an analysis of standard deviation. While genre analysis has today become standard practice across ESP and text-linguistic research, the second method is relatively unknown in the literature and contributes a potentially new approach to the study of voice. The purpose of the second method, an analysis of standard deviation (hereafter, SD analysis; see Figure 1), is to measure the linguistic features of voice by examining how six writers in geology use the features of disciplinary voice to construct and cultivate their self-representation over time. 


\subsection{Description of SD analysis}

As illustrated in Figure 1, standard deviation indicates that each genre feature targeted for analysis in a corpus occurs within a range of occurrences in relation to a mean average. This range of occurrences represents a genre feature's standard deviation, which is often visually portrayed by a bell-shaped Gaussian curve. The area inside the curve is called the spread range, and represents the statistical likelihood that the largest number of a genre feature's occurrences lies between the values that delimit the range. The average value of a genre feature ('l') lies toward the middle of the spread range and indicates the largest grouping of items (i.e., the greatest frequency of occurrence, or average use). While many users of a genre's features reproduce them in ways that are similar, and therefore identifiable (Bazerman, 1988; Miller, 1984; Swales, 1990), we know today that genres are also characterized by more or less extensive variability (Bhatia, 2005; Coe, Lingard, \& Teslenko, 2002; Devitt, 2004). The spread range accounts for this variation by also indicating the number of normal occurrences beyond the average value. Thus, while a typical corpus analysis provides a single representative value for a behavior (' $67 \%$ average occurrence'), $\mathrm{SD}$ analysis accounts for attested variation in that behavior. The range of genre variation is obtained by adding and subtracting the SD value from the average value ('average + and SD', as in 'the range of variation is $.54-.80$, where the average $=.67$ and $\mathrm{SD}=.13$ ). A standard spreadsheet program is used to automatically calculate both the average and the standard deviation values.

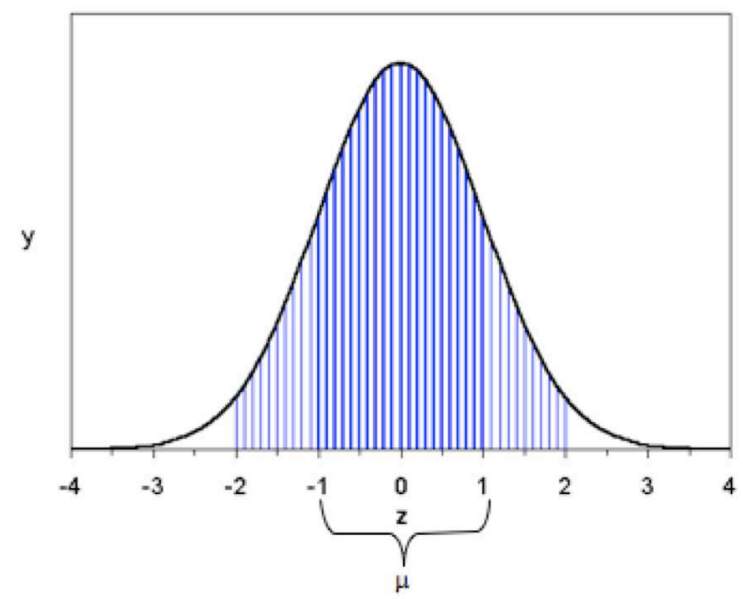

Fig. 1. Gaussian curve showing the spread range for a given genre feature.

With SD analysis, genre behavior is no longer characterized as a single value, but as a range of values. As long as the occurrences of a genre feature fall within the spread range, they can be considered 'normal', or expected, based on a corpus. The usefulness of SD analysis for studying voice is thus found in the possibilities it offers for examining individual uses of particular genre features in comparison to a corpus average. SD analysis is therefore a potentially interesting methodology for studying voice in disciplinary writing because it allows writing researchers to quantify - rather than simply qualify - the 'uniqueness' of an individual's disciplinary voice, in comparison to a group of individuals' writing (corpus).

\subsection{Data collection and participants}

The 87,035-word genre corpus consists of 88 English-language field accounts (1000.4 words avg. length) published between 1983 and 2009, in three subfields of geology: geochemistry, petrology, and structural geology (see Appendix for further details). The corpus of 88 field accounts consists of a first set of 65 field accounts published between 1996 and 1999 (Dressen-Hammouda, 2008). The additional 23 field accounts were produced by the six writers in geology targeted for voice analysis, and were published during the approximately ten-year span following each author's $\mathrm{Ph} . \mathrm{D}$. dissertation, spanning the years 1983-2009. Four authors were native speakers of French (A-C, F), one of English (D), and one of 
Slovakian (E); Author E completed all of his undergraduate and graduate study in the United States, and has lived there since the 1970s.

Three French authors (A, B , C) also held two-year post-doctoral positions in an English-speaking country. All authors were primarily responsible for writing the article.

\subsection{Situated genre analysis and description of coding procedures}

The corpus was coded for 13 indexes specifically related to doing fieldwork (also described in DressenHammouda, 2008). Using corpus-driven analysis, the 13 indexes were identified as a posteriori categories. The purpose of a corpus-driven, rather than corpus-based (Tognini-Bonelli, 2001, p. 17) analysis was to identify the features of disciplinary voice specifically associated with modern geological field writing, rather than to validate overall similarities with other types of scientific discourse (e.g., Biber \& Finegan, 1989; Hunston \& Thompson, 2000; Hyland, 1998, 2005a; Salager-Meyer, 1994). Identifying a posteriori categories of this nature, however, requires gaining access to the situated disciplinary context of field geologists' practice. Situated genre analysis (Ahmad, 1997) is fundamental to this task, and involved developing an ethnographic approach combining three qualitative studies on geological field practice, detailed in Dressen-Hammouda (2013): a sociohistorical analysis of fieldwork practices from 1650 to the present (Atkinson, 1999; Bazerman, 1988), participant observations of fieldwork practices (Gilbert \& Mulkay, 1984; Latour, 2001; Latour \& Woolgar, 1979) and textography (Swales, 1998).

Three categories were devised by the author in order to characterize the rhetorical purpose of the field account. These categories serve as notice to other specialists that the researchers warrant credibility because they have actually been in the field to carry out their own fieldwork, and via their field description can reify current frames of interpretation and practice. The categories reflect this purpose by (1) showing that the author was personally invested in the field study ('personalization indexes'); (2) proving the fieldwork was done by the author because she/he gives undeniable details only the author could provide ('doing-the-work indexes'); and (3) demonstrating that the author's fieldwork is embedded within appropriate disciplinary knowledge and frames of interpretation ('disciplinarity indexes'). Examples of the 13 indexes are given below, and are taken from the six authors' 23 field accounts.

\section{Personalization indexes}

We interpret these features as indicating that the pegmatite originated from the anatexis of the host metapelites.

Our observations of the NSZ in the area north of Xanthi indicate that top-toSW shearing at lower levels of the hangingwall unit occurred first at...

The garnet also becomes larger and more abundant closer to the vein. In the area of Xanthi, ... marbles are at least $1.5 \mathrm{~km}$ thick and form the immediate footwall of the main tectonic contact.

Unequivocal field relations show that $\mathrm{B} 2 \mathrm{~N}$ and $\mathrm{B} 3 \mathrm{~N}$ micro-gabbros form thin margins to B2 and $\mathrm{B} 3$ sheets ... so it is impossible for them to have

intruded along the basal contact after formation of the thin marginal zone.
1. Author pronouns/ possessive adjectives

2. Evaluative adjectives and adverbs showing researcher discernment

3. Interpretive comments about field structures, based on field observation

\section{Doing-the-work indexes}

The pegmatites in this study were collected within the NSZ $(4.5 \mathrm{~km}$ northnorthwest of Xanthi, along the Xanthi River; samples P04-13, P04-26 and P04-27) and the CSZ (1 km east of Chepelare; sample P0464).

P04-26 and P04-27 were taken from two pegmatite veins only $\mathbf{2} \boldsymbol{m}$ apart. P0413 is from another vein about $\mathbf{3 0 0} \mathbf{m}$ further $\boldsymbol{e a s t}$, at a roughly equivalent
4. Nominal and verbal markers of researcher activity

5. Metric, angle and direction measurements 
structural level.

In addition, P04-56 comes from above the CSZ, higher in the northwardsdipping metamorphic pile (32 km northwest of Chepelare, along the Vacha valley).

It has uneven boundaries, while the host gneisses contain randomly distributed cm-thick synfolial quartz-feldspar segregations (Fig. 2c).

The Chepelare Shear Zone (CSZ) is exposed in Bulgaria ... The footwall of the $C S Z$ exposes a pile of mesocratic to felsic orthogneisses at least $3 \mathrm{~km}$ thick.

(Author, 2003)
6. Locational adverbs and prepositions, showing researcher movement in the field

7. References to visual field data, such as maps

8. Geographical location of the fieldwork site

9. Self-citation of prior fieldwork

\section{Disciplinarity indexes}

The massif mostly consists of high-grade metamorphic rocks and granitoids and represents the exhumed metamorphic core of the Alpine orogen.

10. Nominal or adjectival field descriptors

... available geochronological data suggest[s] a complex metamorphic evolution spanning Jurassic to late Cenozoic times.

The critical zone postdated the completion of the Steelpoort pericline, because the steeply dipping western limb of the structure is onlapped by gently dipping cumulates that overlie the lower chromitite layers south of Steelpoort.

The Nestos Shear Zone (NSZ) is exposed in Greece and was first described in the 1980s (Papanikolaou and Panagopoulos, 1981; Ivanov, 1981).

\section{Indicators of geological age}

12. Technical verbal adjectives and participles

13. References to others' fieldwork

While some may argue against the inclusion of some of these indexes, questioning their relevance for creating the perception of disciplinary voice in field geology (e.g., 'measurements', 'locational adverbs') because such indexes are not necessarily unique to field geology or because their inclusion implies that 'just about anything' could count as an index of disciplinary voice, two elements are cited in support of the inclusion of all 13 indexes. The first is the role indexicality plays in the construction of disciplinary expertise. As noted by Dressen-Hammouda (2013, p. 12), the

function of indexicality is to elicit the activation of specific semiotic associations, or inferential structures, ... by means of specific linguistic forms in the text. Knowledgeable insiders glean relevant meaning from linguistic form when [their] recognition of the associated semiotic resources they share is activated, but without what is being 'communicated' necessarily appearing explicitly.

Arguably, the only way to gain access to such knowledge is either to (1) become a practicing field geologist, or (2) gain access to their practices using an ethnographic approach. As discussed in DressenHammouda (2013), blending the results of three types of qualitative analysis (sociohistorical analysis, participant observations of disciplinary practices, and textography) revealed how the indexes reflect the historically situated concerns of geologists' field practice. The indexes' semiotic associations, first identified through sociohistorical analysis, were triangulated using textography and participant observation, which included participating in several geological field trips and listening in on how field geologists talk about their work, thus providing valuable insight about the sorts of information field geologists would find important to convey and/ or identify in published field writing.

Second, the sociocognitive reality of the indexes for creating the perception of disciplinary voice was validated using a small-scale reader response study (e.g., Paul, Charney, \& Kendall, 2001; Tardy \& Matsuda, 2009). In this study (Dressen-Hammouda, 2012), which examined disciplinary readers' sensitivity to the presence or absence of the indexes, five practicing field geologists were asked to evaluate 
three versions of a single field account and to identify the level of the writer's fieldwork expertise: in one version, all personalization and doing-the-work indexes were removed, and disciplinarity indexes were voided of technical detail. In another, original disciplinarity indexes were included, but no personalization indexes and only some doing-the-work indexes (e.g., no measurements, no maps or self-citations) were included. The final version was the field account as originally published. Although space constraints do not allow for detailed discussion of the results here, the study showed that experienced disciplinary readers in field geology are in fact very sensitive to the 13 indexes for evaluating the author's disciplinary identity, level of expertise and credibility. The indexes, due to the mechanisms that generate and maintain in-group and out-group boundaries, are thus unremarkable to non-practitioners, and may even convey a whole different meaning entirely. However, seemingly insignificant devices, like the 13 indexes presented here, clearly provide valuable, situated meaning for disciplinary insiders.

\section{Results and discussion}

The 13 fieldwork indexes were identified and tabulated in all 88 field accounts, and constitute roughly one-half of the field account (Table 1). In order to allow for comparison between the corpus and each writer's use of the indexes, the actual indexical values were 'normalized' by dividing the number of indexes by the total number of words in each field account; numbers were rounded to the third decimal. Table 1 shows the total number of indexes, the average number of indexes per field account, as well as the standard deviation (SD) and range of variation (SD range) for each index.

Table 1 Range of variation for the field account's indexes.

\begin{tabular}{|c|c|c|c|c|}
\hline & $\begin{array}{c}\text { Total \# of } \\
\text { tokens }\end{array}$ & $\begin{array}{c}\text { Avg \# of } \\
\text { tokens }\end{array}$ & $\mathrm{SD}$ & SD Range \\
\hline No. of words & 87035 & 1000.4 & 878.9 & $121.5-1879.3$ \\
\hline No. of indexes & 43250 & 497.1 & 441.1 & $56.0-938.2$ \\
\hline Indexical density & - & .500 & .100 & $.400-.600$ \\
\hline Personalization indexes & 4117 & .047 & .024 & $.024-.071$ \\
\hline 1. $1^{\text {st }}$ person pronouns/poss. adj. & 72 & .001 & .002 & $.000-.003$ \\
\hline 2. Evaluative adj. and adv. & 3222 & .037 & .023 & $.014-.060$ \\
\hline 3. Interpretive comments & 829 & .010 & .006 & $.004-.015$ \\
\hline Doing-the-work indexes & 11243 & .129 & .038 & $.092-.167$ \\
\hline 4.Nominal and verbal activity markers & 2144 & .025 & .016 & $.008-.041$ \\
\hline 5. Metric, angle, direction measures & 2126 & .024 & .015 & $.010-.039$ \\
\hline 6. Locational adverbs and prepositions & 3407 & .039 & .014 & $.026-.053$ \\
\hline 7. References to mapping & 782 & .009 & .007 & $.002-.016$ \\
\hline 8. Geographical location of fieldwork & 2251 & .026 & .016 & $.010-.042$ \\
\hline 9. Self-citation of prior field studies & 537 & .006 & .006 & $.000-.013$ \\
\hline Disciplinarity indexes & 27789 & .319 & .088 & $.231-.408$ \\
\hline 10. Nom. \& adjectival field descrip. & 22799 & .262 & .071 & $.191-.333$ \\
\hline 11. Geological age descriptors & 1602 & .018 & .023 & $.000-.041$ \\
\hline 12. Verbal adjectives and participles & 3112 & .036 & .015 & $.020-.051$ \\
\hline 13. References to others' fieldwork & 915 & .011 & .009 & $.002-.019$ \\
\hline
\end{tabular}

Table 1 also shows that, in some instances, indexes occurred with a frequency close to or less than $1 \%$ (e.g., indexes 1, 3, 7, 9, 13). In addition, some SD values were higher than the average value, resulting in negative values for the lower part of the spread range (e.g., indexes 1,11). These negative values are represented by a zero (SD range). While the significance of linguistic features occurring with such low frequency might be questioned, I will discuss in a later section how situated meaning is not necessarily a function of numerical significance: Even a few occurrences of a single index may strongly influence how specialist readers interpret the author's expertise and credibility. 


\subsection{Description of the authors' use of indexes over time}

Although the sample size is relatively small, the trends observed acrossto similarities in how disciplinary voice develops over time. For example,number of indexes proportional to the number of words in the field account) increases, while remaining within the expected range of variation (.400-.600). What this suggests is that authors do not necessarily use more specialist indexes to signal expertise and credibility to their readers, but instead combine them in different ways and amounts.

In effect, authors later indicate greater personal discernment in their field observations and more explicitly situate themselves in the field for specialist readers. While all authors generally use more personalization indexes over time (author pronouns/possessive adjectives, interpretives), they use more evaluatives in particular (Table 2). The indexicalization of their physical field presence also increases: Indexes of researcher movement (locational adverbs/prepositions) become more frequent (4 of 6 authors), as do geographical location indexes (5 of 6 authors). Interestingly, the use of other doing-the-work indexes decreases (e.g., noun/verbal markers of research activity, measurements). Finally, the overall indexicalization of the authors' disciplinary knowledge increases only slightly or even decreases, mostly remaining within the SD range. This suggests that using more disciplinarity indexes (geological nouns, adjectives and verbs, referring to time or other researchers' fieldwork) is not how authors situate their greater expertise and demonstrate credibility.

Table 2 Six geologists' use of indexes over period of ten years.

\begin{tabular}{|lc||cc||cc||cc||cc||cc||cc|}
\hline & SD range & $\mathbf{A 1}$ & $\mathbf{A 2}$ & $\mathbf{B 1}$ & $\mathbf{B 2}$ & $\mathbf{C 1}$ & $\mathbf{C 2}$ & $\mathbf{D 1}$ & $\mathbf{D 2}$ & $\mathbf{E 1}$ & $\mathbf{E 2}$ & $\mathbf{F 1}$ & $\mathbf{F 2}$ \\
No. of words & $121.5-1879.3$ & 1148 & 2378 & 356 & 645 & 217 & 496 & 2095 & 1090 & 472 & 1025 & 1270 & 975 \\
No. of indexes & $56.0-938.2$ & 625 & 1380 & 181 & 365 & 100 & 257 & 995 & 609 & 274 & 571 & 755 & 538 \\
Indexical density & $.400-.600$ & .544 & .580 & .508 & .566 & .461 & .512 & .475 & .559 & .581 & .557 & .595 & .552 \\
\hline PERSONALIZATION & $.024-.071$ & .070 & .088 & .054 & .074 & .032 & .062 & .067 & .115 & .064 & .100 & .069 & .099 \\
1st person pronoun/adj & $.000-.003$ & .001 & .003 & .000 & .005 & .000 & .000 & .000 & .000 & .000 & .000 & .000 & .002 \\
Evaluatives & $.014-.060$ & .061 & .067 & .048 & .064 & .028 & .058 & .062 & .105 & .057 & .089 & .058 & .090 \\
Interpretives & $.004-.015$ & .008 & .018 & .006 & .006 & .005 & .004 & .005 & .010 & .006 & .012 & .011 & .007 \\
\hline DoING-THE-wORK & $.092-.167$ & .137 & .189 & .180 & .209 & .152 & .163 & .159 & .114 & .165 & .104 & .181 & .186 \\
Nom/verb research & $.008-.041$ & .041 & .040 & .056 & .033 & .051 & .032 & .033 & .032 & .059 & .020 & .057 & .056 \\
Measurements & $.010-.039$ & .015 & .043 & .051 & .048 & .032 & .028 & .022 & .018 & .015 & .002 & .015 & .029 \\
Locational adv/prep & $.026-.053$ & .056 & .066 & .031 & .062 & .028 & .048 & .050 & .034 & .048 & .060 & .051 & .049 \\
References to mapping & $.002-.016$ & .017 & .014 & .008 & .006 & .005 & .012 & .015 & .002 & .006 & .004 & .002 & .008 \\
Geographical location & $.010-.042$ & .005 & .029 & .025 & .043 & .032 & .034 & .017 & .024 & .017 & .021 & .047 & .040 \\
Self-citation fieldwork & $.000-.013$ & .003 & .000 & .008 & .017 & .005 & .008 & .005 & .004 & .015 & .011 & .009 & .003 \\
\hline DisciPLINARITY & $.231-.408$ & .338 & .304 & .274 & .282 & .276 & .292 & .249 & .330 & .352 & .352 & .344 & .266 \\
Nom/adj field descriptors & $.191-.333$ & .277 & .240 & .208 & .228 & .221 & .218 & .204 & .250 & .277 & .292 & .256 & .197 \\
Geological age & $.000-.041$ & .016 & .013 & .039 & .020 & .018 & .044 & .006 & .013 & .013 & .013 & .016 & .010 \\
Technical verb/participles & $.020-.051$ & .038 & .044 & .015 & .025 & .028 & .020 & .035 & .053 & .040 & .033 & .038 & .039 \\
Citation other studies & $.002-.019$ & .006 & .006 & .012 & .009 & .009 & .010 & .003 & .015 & .004 & .015 & .035 & .021 \\
\hline
\end{tabular}

Rather, the quantitative results show that when writing about their fieldwork after ten years of disciplinary experience, field geologists tend to use markedly more of some indexes (evaluatives, locational adverbs/prepositions, geographical location), a bit more of others (author pronouns/adjectives, interpretives), and fewer of others (noun/verbal markers of research activity, measurements, disciplinarity indexes). Such results echo findings by Hyland (2002), for example, who found that less experienced writers (i.e., L2 undergraduates) use fewer author pronouns and determiners than experienced academic writers. What this implies is that through their disciplinary voice, more experienced disciplinary writers 
carefully choose from a set of specialized indexes to convey only specific types of information, having likely learned along the way that such elements are more convincing in creating trust in their readers about the seriousness of their research.

\subsection{Case study of a single author's disciplinary voice}

Is voice, as many have suggested, irrevocably beyond the scope of what readers and writers can consciously perceive? Can SD analysis help researchers better locate the features of disciplinary voice in the text, and thus help student writers in the disciplines to appropriate the effects of their voice more effectively? This final section attempts to answer such questions using a case study, comparing Author F's field writing at the time of her Ph.D. (2000) to how she wrote nine years later, using SD analysis. For the sake of comparison, two similar excerpts (FA-2000 and FA-2009) were selected from the end of each field account, where Author F discusses where the rocks were sampled. Indexes showing authorial discernment ('evaluatives') and placement in the field ('locationals', 'geolocalization', 'direction measurements') are highlighted in bold-faced italics; interpretive comments and first-person pronouns are underlined; sentences are numbered.

\footnotetext{
FA-2000

${ }^{1}$ The sampling strategy was to combine petrological and geochronological studies on carefully-selected samples. ${ }^{2}$ Criteria for selecting samples were as follows. ${ }^{3}$ The only studied eclogite (sample CX5c) was chosen because (1) a $\mathrm{U}-\mathrm{Pb}$ zircon age was previously obtained from it (Paquette 1987) and (2) it appeared to be a good candidate for $\mathrm{Sm}-\mathrm{Nd}$ and $40 \mathrm{Ar} / 39 \mathrm{Ar}$ dating because of the abundance of garnet and the presence of phengite. ${ }^{4} \mathrm{This}$ eclogite was collected in a quarry (la Bréhardière) located on the left bank of the Loire River, 2 km southwest of la Varenne (Figure 1). ${ }^{5}$ The other selected rocks, which represent a large spectrum of whole-rock compositions, were collected in two closely-spaced localities, namely Fay-de-Bretagne and Campbon (Figure 1). ${ }^{6}$ They consist of three mica-schists (FAY 24, FAY 29 and CH 20), a leptynite (FAY 13) and a quartz vein (CAM 5).
}

\section{FA-2009}

${ }^{1}$ The pegmatites in this study were collected within the NSZ (4.5 km north-northwest of Xanthi, along the Xanthi River; samples P04-13, P04-26 and P04-27) and the CSZ (1 km east of Chepelare; sample P04- 64). ${ }^{2}$ In addition, P04-56 comes from above the CSZ, higher in the northward-dipping metamorphic pile (32 km northwest of Chepelare, along the Vacha valley). ${ }^{3}$ The samples from the NSZ lie at lower levels of the hangingwall unit, structurally about $1 \mathbf{~ k m}$ above the contact, with thick marbles in the footwall unit. ${ }^{4} \mathrm{P} 04-26$ and P04-27 were taken from two pegmatite veins only 2 m apart. ${ }^{5} \mathrm{P} 04-13$ is from another vein about 300m further east, at a roughly equivalent structural level. ... ${ }^{6}$ We interpret these features as indicating that the pegmatite originated from the anatexis of the host metapelites. ${ }^{7} \mathrm{P} 04-27$ is also a pegmatite vein of irregular thickness (up to $30 \mathrm{~cm}$ ) with an internal foliation paralleling that of the hosting biotite-garnet gneisses. ${ }^{8}$ It has uneven boundaries, while the host gneisses contain randomly distributed $\boldsymbol{c m}$-thick synfolial quartz-feldspar segregations (Fig. 2c).... ${ }^{9}$ The garnet also becomes larger and more abundant closer to the vein. ${ }^{10}$ These features suggest that this pegmatite, too, originated from anatexis of its host gneisses.

Upon a first reading, the later field account indeed appears to show a greater indexicalization of the author's fieldwork. In effect, the early FA-2000 indicates where the rocks were sampled (sentences 4-5: 'was collected in a quarry', 'were collected in two closely-spaced localities'), whereas FA-2009 more amply describes the sampling environment using more locational adverbs/prepositions, measurements and evaluatives (sentences 1 and 4: " were collected within the NSZ (4.5 km north-northwest of Xanthi, along the Xanthi River', ' $\mathrm{P} 04-13$ is from another vein about 300m further east, at a roughly equivalent structural level'). The 'field talk' and references to physical field presence in FA-2009 seem more frequent, whereas in FA-2000 there appears to be less 'field talk' and more 'meta-talk': while the author uses some interpretives (sentence 3, 'it appeared to be a good candidate...'), her purpose would appear to carefully justify the validity of the samples chosen (sentence 1, 'carefully-selected samples'). In the later FA-2009, in contrast, the author no longer justifies her sampling choices, by omission implying that the samples were relevant. She does strongly suggest their relevance, however, by using more author pronouns and interpretive comments to show how the observed structures fit into a larger interpretive 
frame (sentences 6 and 10: 'We interpret these features as indicating that', 'These features suggest that'). The author 'seems' more confident nine years later, and questions the validity of her contributions less, just describing her fieldwork rather than trying to thwart potential criticism. Such impressions are supported by SD analysis, which reveals areas in which Author F indexes her expertise more frequently.

Table 3 SD analysis of Author F's field writing strategies over time

\begin{tabular}{lccc}
\hline & Corpus SD range & FA- 2000 & FA-2009 \\
\hline No. of Words & & 139 & 389 \\
No. of Indexes & $.400-.600$ & 74 & 245 \\
Indexical density & & .532 & .629 \\
PERSONALIZATION & $.000-.003$ & .000 & .002 \\
Author pronouns/poss adj & $.014-.060$ & .050 & .126 \\
Evaluatives & $.004-.015$ & .014 & .010 \\
Interpretives & & & .087 \\
DoING-THE-wORK & $.008-.041$ & .230 & .046 \\
Nom/verb field activity & $.010-.039$ & .014 & .064 \\
Measurements & $.026-.053$ & .036 & .013 \\
Locational adv/prep & $.002-.016$ & .014 & .023 \\
References to mapping & $.010-.042$ & .036 & .000 \\
Geographical location & $.000-.013$ & .007 & .036 \\
Self-citation fieldwork & & & .000 \\
DisciPLINARITY & $.191-.333$ & .115 & .014 \\
Nom/adj field descriptors & $.000-.041$ & .014 & .000 \\
Geological age & $.020-.051$ & $.002-.019$ & \\
Technical verb/participles & & \\
Citation other studies & & & .000 \\
\hline
\end{tabular}

Table 3, comparing the author's indexical strategies over time, shows that FA-2009 surpasses the range of variation for five of the indexical indicators (density, evaluatives, noun/verb markers of field activity, measurements, and locational adverbs/prepositions), similar to the trends seen for the other authors all the while being unique to the author's particular writing situations. Table 3, for example, suggests that the author has later chosen to silence some things (using far fewer noun/ verb markers of field activity) in order to say others, carefully choosing from her discipline's repertoire of semiotic resources to index her research activity, and as a result, increased experience. The combined effect of the indexical interweaving is that the perceived voice of her later writing may more effectively communicate a visual representation of the study site (one can 'see' the field better), allowing for greater reduplicability and therefore greater credibility.

When interviewed about these changes, and responding to my contrastive analysis of her earlier and later field writing, however, Author F expressed doubt about whether her later text was truly more 'credible' than her earlier one. She did not remember 'feeling' less credible in 2000, and was not aware that she may have suggested in her earlier field writing that she might be less credible or competent. Such comments echo the difficulties readers and writers seem to have in making explicit the full rhetorical effect of disciplinary voice (Tardy, 2012), and in controlling the portrayal of a particular identity (Ivanic ${ }^{2}, 1998$ ). At the same time, it is revealing and quite interesting to note that Author F also participated as one of the five evaluators in the reader-response study described earlier, and was sensitive to these same indexes when evaluating the various levels of field experience in someone else's writing, along the lines described earlier. In that regard, conscious awareness of the indexes of expertise appears difficult to control, and one's reaction to the indexes may not necessarily be the same depending on whether one is in the role of the reader or the writer. It is also conceivable that an author's shifting use of the indexes of expertise over 
time may simply be a reflection of that author's increasing ability to conceptualize readers' expectations and reactions in a particular community.

By way of some initial conclusions, a couple of cautious statements must be made. Despite its potential, clearly, one needs to use the results of SD analysis carefully, keeping in mind that numerical results are purely indicators and no proof of any singular, overarching 'reality'. Thus, a tentative use of SD analysis could be as an aid for tracking the features of disciplinary voice, whose indexicality must then be further validated using situated genre analysis coupled with ethnographic methods, and corroborated by readers' impressions, reader-response studies and text-based interviews. In other words, textual analysis alone is insufficient for identifying and measuring voice accurately.

\section{Conclusion}

The indexes described here are clearly not generalizable across all disciplinary discourses, because they are very closely tied to the practices and history of a single discipline. Instead, this study has attempted to demonstrate a method for showing how a close, situated reading of the indexes of disciplinary voice may help writing researchers better apprehend and describe voice. Accordingly, a strong argument is made in favor of situated genre analysis, because analysis without triangulation of specific sociohistorical context is insufficient, especially when dealing with the complexities of voice and indexicality. In addition, a corpus-driven genre analysis of recurring linguistic features, especially when examined longitudinally, can reveal a good deal about how experienced writers use the features of disciplinary voice to more convincingly construct their self-representation and others' perception of their expertise. The results have shown that the features of disciplinary voice evolve in correlation with a writer's professional experience, thereby indexing one's institutional status within the disciplinary community. Further research needs to investigate whether the indexes specific to other disciplinary communities also evolve in similar ways.

Disciplinary voice is thus a set of situated semiotic resources we use to show who we are socially, how much we belong, and how much we can be trusted about what we are saying. Inevitably, some of the features discussed here may seem unwarranted, but the argument made here, following Matsuda (2001) and later Tardy and Matsuda (2009), has been that all these features contribute to the ongoing impression of disciplinary voice. Although their numerical incidence may be low, indexes play a crucial role in shaping how specialist readers interpret the writer's disciplinary voice and situate their expertise. Readerresponse data and situated analysis are both essential for revealing which indexes are relevant, even those which a priori do not seem specifically connected to voice.

Finally, SD analysis is a useful tool for examining disciplinary voice because it captures both the regularities as well as the individuality and variation inherent in genre use. It shows the normal range of variation in a corpus, and excludes the lowestfrequency outliers from the range of the 'norm'. It can thus also indicate what might be an atypical use of genre features. As was argued here, such variations from the norm may indicate something particular about an author's disciplinary status, especially when similar tendencies are found for other authors with a similar status. Clearly, a significant amount of variation characterizes individual voice. At the same time, however, there is sufficient similarity in the development of writing strategies across individuals to warrant that more attention be paid to the unique strategies each individual implements in her or his writing and what this means about the process of disciplinary becoming and emergence of writing expertise, in general. Helping L2 writing become aware of the socially and institutionally relevant uses of disciplinary voice, and showing them how appropriate voice is tied to their own process of 'disciplinary becoming' (Dressen-Hammouda, 2008), can in this regard be useful.

\section{Acknowledgments}

Sincere thanks to all anonymous reviewers for their thoughtful comments and careful reviews, which greatly helped to improve the quality of this paper. 


\section{Appendix A}

Table A1. Corpus of field accounts (Dressen-Hammouda, 2008)

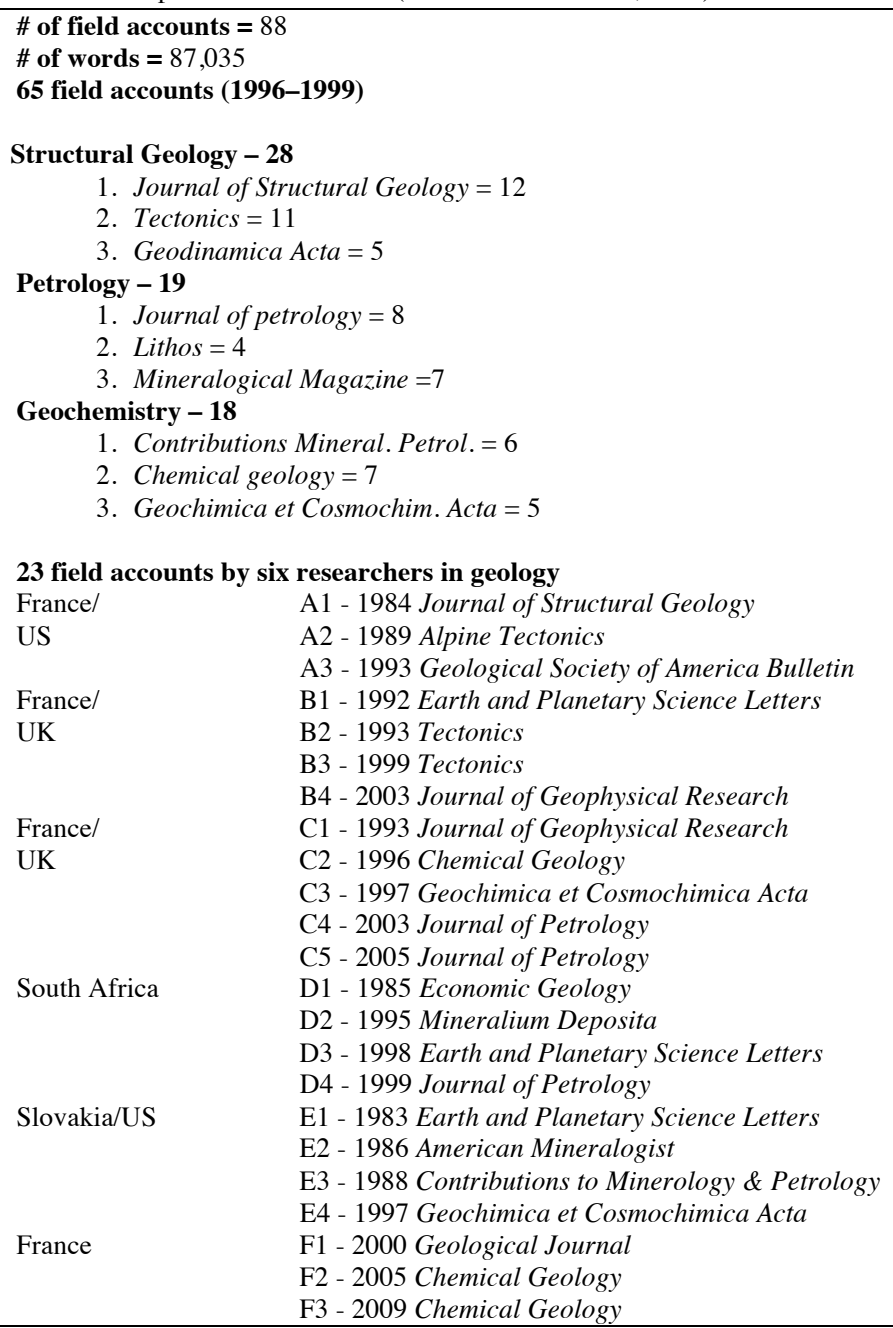

\section{References}

Ahmad, U. (1997). Research article introductions in Malay: Rhetoric in an emerging research community. In A. Duszak (Ed.), Culture and Styles of Academic Discourse (pp. 273-304). Berlin: Mouton de Gruyter.

Atkinson, D. (1999). Scientific discourse in sociohistorical context: The Philosophical Transactions of the Royal Society of London, $1675-1975$. Mahwah, NJ: Lawrence Erlbaum Publishers.

Atkinson, D. (2001). Reflections and refractions on the JSLW special issue on voice. Journal of Second Language Writing, 10 , $107-124$.

Bakhtin, M. (1981). The dialogic imagination: Four essays by M. M. Bakhtin, in M. Holquist (ed.) (C. Emerson and M. Holquist, trans.). Austin: University of Texas Press.

Bazerman, C. (1988). Shaping written knowledge: The genre and activity of the experimental article in science. Madison: University of Wisconsin Press.

Belcher, D. (2007). Seeking acceptance in an English-only research world. Journal of Second Language Writing, 16, 1-22.

Bhatia, V. K. (2005). Worlds of written discourse. London, UK: Continuum.

Bucholtz, M., \& Hall, K. (2005). Identity and interaction: A sociocultural linguistic approach. Discourse Studies, 7, 585-614.

Blommaert, J. (2010). The sociolinguistics of globalization. Cambridge: Cambridge University Press.

Coe, R., Lingard, L., \& Teslenko, T. (Eds.). (2002). The rhetoric and ideology of genre: Strategies for stability and change. Cresskill, NJ: Hampton.

Davies, A., Hamp-Lyons, L., \& Kemp, C. (2003). Whose norms? International proficiency tests in English. World Englishes, $22,571-584$.

Devitt, A. (2004). Writing genres. Carbondale: Southern Illinois University Press.

Dressen-Hammouda, D. (2008). From novice to disciplinary expert: Disciplinary becoming and genre mastery. English for Specific Purposes, 27, $233-252$.

Dressen-Hammouda, D. (2012). Place and space as shapers of disciplinary identity: A multimodal analysis of disciplinary becoming. Invited plenary presented at the "Space, place and the discursive construction of identity conference", Università degli Studi di Napoli l'Orientale, Naples (Italy), 3-5 June.

Dressen-Hammouda, D. (2013, In press). The role of indexicality in the emergence of disciplinary writing expertise. In J. Bamford (Ed.), Space, place and the discursive construction of identity. 
Elbow, P. (1994). Introduction. In P. Elbow (Ed.), Landmark essays on voice and writing (pp. xi-xvii). Mahwah, NJ: Lawrence Erlbaum Publishers.

Elbow, P. (1999). Individualism and the teaching of writing: Response to Vai Ramanathan and Dwight Atkinson. Journal of Second Language Writing, 8, 327-338.

Ericsson, K. A. (2006). The influence of experience and deliberate practice on the development of superior expert performance. In K. A. Ericsson, N. Charness, R. Hoffman, \& P. Feltovich (Eds.), The Cambridge Handbook of Expertise and Expert Performance (pp. 638-704). Cambridge: Cambridge University Press.

Gilbert, G. N., \& Mulkay, M. (1984). Opening the Pandora's Box: A sociological analysis of scientific discourse. Cambridge: Cambridge University Press.

Helms-Park, R., \& Stapleton, P. (2003). Questioning the importance of individualized voice in undergraduate L2 argumentative writing: An empirical study with pedagogical implications. Journal of Second Language Writing, 12, 245-265.

Hirvela, A., \& Belcher, D. (2001). Coming back to voice: The multiple voices and identities of mature multilingual writers. Journal of Second Language Writing, 10,83-106.

Hunston, S., \& Thompson, G. (Eds.). (2000). Evaluation in text: Authorial stance and the construction of discourse. Oxford: Oxford University Press.

Hyland, K. (1998). Hedging in scientific research articles. Amsterdam: John Benjamins.

Hyland, K. (2000). Disciplinary discourses: Social interactions in academic writing. Harlow, UK: Longman.

Hyland, K. (2002). Authority and invisibility: Authorial identity in academic writing. Journal of Pragmatics, 34, $1091-1112$.

Hyland, K. (2005a). Representing readers in writing: Student and expert practices. Linguistics and Education, 16, $363-377$.

Hyland, K. (2005b). Stance and engagement: A model of interaction in academic discourse. Discourse Studies, 7, $173-191$.

Hyland, K. (2010). Constructing proximity: Relating to readers in popular and professional science. Journal of English for Academic Purposes, 9 , $116-127$.

Hyland, K., \& Anan, E. (2006). Teachers' perceptions of error: The effects of first language and experience. System, 34, 509-519.

Hyland, K., \& Sancho Guinda, C. (Eds.). (2012). Stance and voice in written academic genres. New York: Palgrave Macmillan.

Ivanič, R. (1998). Writing and identity: The discoursal construction of identity in academic writing. Amsterdam: John Benjamins.

Ivanič, R., \& Camps, D. (2001). I am how I sound: Voice as self-representation in L2 writing. Journal of Second Language Writing, $10,3-33$.

Jarvis, S., Grant, L., Bikowski, D., \& Ferris, D. (2003). Exploring multiple profiles of highly rated learner compositions. Journal of Second Language Writing, 12(4), 377-403.

Latour, B. (2001). L'espoir de Pandore: Pour une version réaliste de l'activité scientifique. Paris: Éditions la Découverte.

Latour, B., \& Woolgar, S. (1979). Laboratory life: The social construction of scientific facts. Beverley Hills, CA: Sage Publications.

Lave, J., \& Wenger, E. (1991). Situated learning: Legitimate peripheral participation. Cambridge University Press.

Leki, I. (2006). Negotiating socioacademic relations: English learners' reception by and reaction to college faculty. Journal of English for Academic Purposes, 5, 136-152.

Lillis, T. (2008). Ethnography as method, methodology, and "deep theorizing": Closing the gap between text and context in academic writing research. Written Communication, 25, 353-388.

Lillis, T., \& Curry, M. J. (2010). Academic writing in a global context: The politics and practices of publishing in English. London: Routledge.

Matsuda, P. (2001). Voice in Japanese written discourse: Implications for second language writing. Journal of Second Language Writing, 10, 3553.

Matsuda, P., \& Jeffery, J. (2012). Voice in student essays. In K. Hyland \& C. Sancho Guinda (Eds.), Stance and voice in written academic genres (pp. 151-165). New York: Palgrave Macmillan.

Matsuda, P., \& Tardy, C. (2007). Voice in academic writing: The rhetorical construction of author identity in blind manuscript review. English for Specific Purposes, 26, 235-249.

Matsuda, P., \& Tardy, C. (2008). Continuing the conversation on voice in academic writing. English for Specific Purposes, $27,100-105$.

Miller, C. (1984). Genre as social action. Quarterly Journal of Speech, 70, 151-167.

Mur-Dueñas, P., Lorés-Sanz, R., \& Lafuente-Millán, E. (2010). Editorial for special issue on interpersonality. Journal of English for Academic Purposes, 9, 83-85.

Ochs, E. (1992). Indexing gender. In A. Duranti \& C. Goodwin (Eds.), Rethinking context: Language as an interactive phenomenon (pp. 335358). Cambridge: Cambridge University Press.

Paul, D., Charney, D., \& Kendall, A. (2001). Moving beyond the moment: Reception studies in the rhetoric of science. Journal of Business and Technical Communication, 15, 372-399.

Prior, P. (2001). Voices in text, mind, and society: Sociohistoric accounts of discourse acquisition and use. Journal of Second Language Writing, $10,55-81$.

Ramanathan, V., \& Atkinson, D. (1999). Individualism, academic writing, and ESL writers. Journal of Second Language Writing, 8, 45-75.

Ramanathan, V., \& Kaplan, R. (1996). Audience and voice in current L1 composition texts: Some implications for ESL student writers. Journal of Second Language Writing, 5, 21-34.

Salager-Meyer, F. (1994). Hedges and textual communicative function in medical English written discourse. English for Specific Purposes, 13, 149-179.

Stapleton, P. (2002). Critiquing voice as a viable pedagogical tool in L2 writing: Returning the spotlight to ideas. Journal of Second Language Writing, 11, 177-190.

Stapleton, P., \& Helms-Park, R. (2008). A response to Matsuda and Tardy's "Voice in academic writing: The rhetorical construction of author identity in blind manuscript review". English for Specific Purposes, 27, 94-99.

Swales, J. M. (1990). Genre analysis: English in academic and research settings. Cambridge: Cambridge University Press.

Swales, J. M. (1998). Other floors, other voices: A textography of a small university building. Mahwah, NJ: Lawrence Erlbaum Publishers.

Swales, J. M. (2004). Research genres: Explorations and applications. Cambridge: Cambridge University Press.

Tardy, C. (2012). Current conceptions of voice. In K. Hyland \& C. Sancho Guinda (Eds.), Stance and voice in written academic genres (pp. 3448). New York: Palgrave Macmillan.

Tardy, C., \& Matsuda, P. (2009). The construction of author voice by editorial board members. Written Communication, $26,32-52$.

Tognini-Bonelli, E. (2001). Corpus linguistics at work. Amsterdam: John Benjamins.

Zhao, C. G., \& Llosa, L. (2008). Voice in high-stakes L1 academic writing assessment: Implications for L2 writing instruction. Assessing Writing, $13,153-170$. 